\title{
BUDAYA KERJA DALAM PENGEMBANGAN KINERJA GURU MTS DI KABUPATEN DEMAK
}

\section{WORKING CULTURE IN DEVELOPING THE PERFORMANCES OF MTS TEACHERS IN DEMAK REGENCY}

\author{
Noor Miyono \\ Universitas PGRI Semarang; \\ Jl. Sidodadi Timur No.24 - Dr.Cipto, Semarang \\ e-mail: noormiyono@upgris.ac.id \\ Ngurah Ayu Nyoman M \\ Universitas PGRI Semarang; \\ Jl. Sidodadi Timur No.24 - Dr.Cipto, Semarang \\ e-mail: ngurahayunyomanmuniati@yahoo.com
}

Naskah diterima tanggal 16 juli 2018, Naskah direvisi tanggal 5 Oktober 2018, Naskah disetujui tanggal 5 November 2018

\begin{abstract}
Abstrak
Kepala madrasah memiliki tanggung jawab yang besar dalam menciptakan situasi belajar mengajar yang baik. Budaya kerja yang baik dapat menumbuhkan bagaimana mutu dan kinerja dilaksanakan oleh seorang guru yang berada dalam satuan unit organisasi kerja. Populasi penelitian ini adalah guru MTs di Kabupaten Demak dengan sampel 135 guru yang dipilih dengan kuota purposive random sampling. Pengambilan data melalui kuesioner, pengolahan data serta uji regresi tunggal dan regresi ganda menggunakan SPSS. Hasil penelitian menunjukkan bahwa reponden mempersepsikan peran kepala madrasah pada kategori baik, budaya kerja dipersepsikan baik dan kinerja guru juga termasuk kategori baik. hasil uji regresi menunjukkan (1) peran kepala madrasah berpengaruh singifikan terhadap kinerja guru madrasah sebesar 55,5\% (2) budaya kerja berpengaruh signifikan terhadap kinerja guru sebesar 69,2 \% (3) peran kepala madrasah dan budaya kerja secara bersama-sama berpengaruh signifikan terhadap kinerja guru sebesar $54,8 \%$, persamaan regresi dengan koefisien positif $\hat{Y}=14,025+0,584 \mathrm{X}_{1}$ $+0,637 \mathrm{X}_{2}$.
\end{abstract}

Kata kunci: budaya kerja, guru, kinerja, pengembangan, kepala sekolah

\begin{abstract}
The Principal of Madrasah have a great responsibility in creating good teaching and learning situations. A good work culture can foster how quality and performance are carried out by a teacher who is in the unit of the work organization unit. The population of this study was MTs teachers in Demak Regency with a sample of 135 teachers selected with purposive random sampling quota. Data collection through questionnaires, data processing and single regression test and multiple regression using SPSS. The results show that respondents perceive the role of madrasah heads in good categories, perceived work culture and teacher performance are also good categories. Regression test results showed (1) the role of madrasah heads had a significant effect on the performance of madrasah teachers by 55.5\% (2) work culture had a significant effect on teacher performance by $69.2 \%$ (3) the role of madrasah heads and work culture jointly influential significant to teacher performance by 54.8\%, regression equation with positive coefficient koefisien $=14.025$ $+0.584 X 1+0.637 X 2$.
\end{abstract}

Keywords: working culture, teacher, performance, development, principal

\section{PENDAHULUAN}

S alah satu isu penting dalam penyelenggaraan pendidikan saat ini adalah peningkatan mutu pendidikan, serta membudayakanya. Dalam
Undang-undang nomor 20 tahun 2003 tentang Sistem Pendidikan Nasional pasal 4 ayat 6 menegaskan bahwa pendidikan diselenggarakan dengan memberdayakan semua komponen masyarakat 
melalui peran serta dalam penyelenggaraan dan pengendalian mutu layanan pendidikan. Pendidikan adalah usaha mengembangkan potensi peserta didik dengan tujuan agar mereka memiliki kepribadian secara holistik. Nilai-nilai yang akan ditanamkan dalam pendidikan meliputi: spiritual keagamaan, pengendalian diri, kepribadian, kecerdasan, akhlak mulia serta keterampilan yang diperlukan pribadinya, masyarakat, bangsa dan negara.

Madrasah merupakan lembaga pendidikan formal yang bersifat kompleks dan unik, sehingga memerlukan tingkat koordinasi yang tinggi. Lembaga ini dipimpin oleh seorang Kepala madrasah yang memang merupakan kunci dari perubahan lembaga yang dipimpinnya. Kepala sekolah (madrasah) yang berhasil apabila ia memahami keberadaan sekolah-nya sebagai organisasi yang kompleks dan unik, serta mampu melaksanakan peranan sebagai seseorang yang diberi tanggung jawab untuk memimpin sekolah (Wahjosumidjo, 2007: 81)

Guru, dosen atau tenaga pendidik pada umumnya adalah bagian penting dari organisasi pendidikan yang disebut sekolah atau madrasah. Kehadiran tenaga pendidik, tidak bisa melepaskan diri dari kehadiran lembaga pendidikan sebagai sebuah institusi. Dalam konteks itu pula, perilaku guru senantiasa berinteraksi dengan konteks dan/ atau situasi lembaga pendidikan. Dalam setiap tindakannya, baik yang menyangkut pikiran, perkataan, dan perbuatan seorang guru, akan menjadi bagian penting dari proses pelayanan atau manajemen pendidikan.

Pemimpin suatu lembaga pendidikan (madrasah), tidak saja dituntut menguasai teori kepemimpinan, seorang kepala madrasah juga harus terampil dalam membaca situasi di lingkungan kerjanya. Kepala madrasah harus mempunyai etos kerja yang tinggi untuk menjadikan lembaga pendidikan yang dipimpinnya lebih berkualitas sesuai tuntutan masyarakat. Kepala madrasah harus memiliki konsep kepemimpinan yang baik, mempunyai kompetensi dan kaya pengalaman agar mampu mendorong kinerja tenaga pendidiknya.

Fungsi utama pimpinan pada satuan pendidikan, seperti kepala madrasah adalah menciptakan situasi belajar mengajar yang menyenangkan bagi guru dan peserta ddik sehingga guru dapat mengajar dengan penuh kreatif dan peserta didik dapat belajar dengan baik. Dalam melaksanakan fungsi tersebut, kepala madrasah memiliki tanggung jawab yang besar yaitu dalam melaksanakan tugas pokok fungsinya sebagai kepala madrasah dapat tercipta situasi belajar mengajar yang baik sehingga kompetensi guru bertambah dan menjadi professional. Dalam prakteknya di lapangan, seorang kepala madrasah menghadapi tantangan yang berat, untuk itu ia harus memiliki persiapan memadai dalam melaksanakan pekerjaannya, khususnya dalam meningkatkan kompetensi dan kinerja tenaga pendidik di lembaga yang dipimpinnya, sehingga mampu menciptakan budaya kerja dan suasana pendidikan serta pembelajaran yang efektif dan efisien.

Hal tersebut sejalan dengan hasil penelitaian Taulabi(2015)kepala madrasahakan mempengaruhi para guru dalam pembelajaran dan semangat belajar. Jika pemimpin dapat mengatur dan membimbing guru-guru secara baik dan tepat, para guru dapat melaksanakan tugas-tugasnya dengan penuh tanggung jawab, konsisten, memperhatikan kepentingan bawahan sehingga tidak ada keluhan dalam menjalankan tugas dan kewajiban seharihari, harus menunjukkan kewibawaannya seharihari, sehingga dapat diteladani dan dipatuhi oleh para guru maupun siswa. Penelitian Hikmah (2014) menyimpulkan bahwa kepala madrasah sebagai leader, harus mempunyai keteladanan yang baik dan mampu untuk menggerakkan bawahannya, terlihat dari teladan sikap dan perilaku terhadap para guru dan tenaga tata usaha.

Madrasah sebagai salah satu bagian sistem pendidikan Nasional tentu memerlukan perhatian dan pengelolaan secara serius. Karena itu, kepala madrasah ke depan dengan perubahan masyarakat yang semakin cepat dan terbuka menuntut kemampuan yanglebih kreatif, inovatif dan dinamis. Kepala madrasah yang sekedar bergaya menunggu dan terlalu berpegang pada aturan-aturan birokratis dan berfikir secara struktural dan tidak berani melakukan inovasi untuk menyesuaikan tuntutan masyarakatnya, akan ditinggalkan oleh peminatnya. Pada masyarakat yang semakin berkembang demikian cepat dan didalamnya terjadi kompetisi secara terbuka selalu dituntut kualitas pelayanan yang berbeda dengan masyarakat sebelumnya (Suprayogo, 2004: 212)

Kepala madrasah harus dapat melaksanakan semua tugas pokok fungsinya yang menjadi tanggung jawabnya. Jika tanggung jawab tidak dilaksanakan maka selain tujuan yang diharapkan tidak akan tercapai, juga akan menurunnya kinerja guru dan muru madrasah. Oleh karena itu, peran dan 
tugas seorang pemimpin itu sangat berat termasuk pemimpin Madrasah (kepala madrasah) yang sangat berperan dalam keberhasilan pendidikan di madrasah dan salah satunya tak terlepas dari peran kepala madrasah dalam mengembangkan budaya kerja pada gurunya.

Budaya kerja dapat menumbuhkan bagaimana mutu dan kinerja dilaksanakan oleh seorang guru yang berada dalam satuan unit organisasi kerja. Bagaimana kebiasaan bekerja untuk memperbaiki diri dirasakan sebagai bagian dari kehidupannya. Budaya ini dalam kaitannya dengan penciptaan kepuasaan pihak yang dilayani sangat penting, sebab setiap guru akan dapat merasakan peningkatan diri dan memperbaiki diri bukan lagi suatu paksaan yang datang dari seorang pemimpin sebagai suatu pembinaan, melainkan dirasakan sebagai suatu bagian yang integral dari keharusan diri seseorang dalam memecahkan masalah kerja dalam hal ini mengajar.

Budaya kerja adalah suatu falsafah dengan didasari pandangan hidup sebagai nilai-nilai yang menjadi sifat, kebiasaan dan juga pendorong yang dibudayakan dalam suatu lembaga pendidikan dan tercermin dalam sikap menjadi perilaku, cita-cita, pendapat, pandangan serta tindakan yang terwujud sebagai kerja. Suatu keberhasilan kerja, berakar pada nilai-nilai yang dimiliki dan perilaku yang menjadi kebiasaannya. Seorang guru yang profesional selalu taat, aturan, taat budaya kerja, serta memiliki etos kerja di dalam kesadaran tanggung jawab dan integritas. Profesionalisme guru dibutuhkan untuk memperkuat budaya kerja. Begitu pula sebaliknya, budaya kerja dibutuhkan untuk meningkatkan profesionalisme guru. Budaya kerja ini dimaksudkan sebagai suatu identitas dalam meningkatkan dan mengembangkan sekolah secara umum yang salah satunya tercermin dari sikap profesionalisme para guru. Sehingga diharapkan dengan adanya suatu budaya kerja yang diyakini dan dapat dilaksanakan bersama dengan penuh kesadaran akan dapat meningkatkan profesionalisme guru yang tinggi.

Budaya kerja guru madrasah harus dipegang bersama oleh kepala sekolah, guru, staf administrasi dan siswa sebagai dasar dalam memahami dan memecahkan berbagai persoalan yang muncul di madrasah. Budaya kerja pada dasarnya merupakan suatu sistem nilai yang di ambil maupun dikembangkan oleh suatu organisasi/institusi sehingga menjadi aturan yang dipakai sebagai pedoman berfikir dan bertindak dalam rangka mencapai suatu tujuan organisasi. Nilai-nilai budaya kerja menunjukkan intensitas budaya kerja, yaitu sejauhmana karyawan menerima dan menjadi budaya kerja serta sebagai landasan perilaku dalam bekerja.

Budaya kerja juga dapat difungsikan sebagai tuntunan yang mengikat para anggota pegawai suatu organisasi, maka individu yang ada pada lembaga secara tidak langsung akan terikat sehingga dapat membentuk sikap dan perilaku dengan visi dan misi lembaga. Proses tersebut akan membentuk individu sebagai pegawai yang berkualitas, berintegritas tinggi yang nantinya akan menghasilkan sumberdaya manusia yang berkualitas dan kompeten. Dewi (2008: 3) budaya kerja adalah suatu falsafah dengan didasari pandangan hidup nilai-nilai yang menjadi sifat, kebiasaan, dan juga pendorong yang dibudayakan dalam suatu kelompok dan tercermin dalam sikap, menjadi perilaku, cita-cita, pendapat, pandangan, serta tindakan yang terwujud sebagai kerja.

Melaksanakan budaya kerja dalam suatu lembaga atau organisasi mempunyai arti yang sangat dalam, karena akan merubah sikap dan perilaku sumber daya manusia untuk dapat mencapai produktivitas kerja yang tinggi. Jadi budaya kerja dalam penelitian ini merupakan pandangan hidup yang harus diiliki pegawai sebagai nilai-nilai yang harus menjadi sifat, kebiasaan dan kekuatan pendorong kerja, membudaya dalam kehidupan pegawai dalam melakukan tugasnya. Hal tersebut kemudian tercermin dari sikap menjadi perilaku, keyakinan, cita-cita dan tindakan yang terwujud sebagai kinerja.

Budaya kerja bagi semua pegawai yang ada dilingkungan Kantor Kementerian Agama meliputi 5 (lima) budaya kerja, yaitu: Integritas. Profesional. Tanggung jawab, Inovasi dan Keteladanan. Pada prinsipnya fungsi budaya kerja bertujuan untuk membangun keyakinan sumberdaya manusia atau menanamkan nilai-nilai tertentu yang melandasi atau mempengaruhi sikap dan perilaku yang konsisten serta komitmen membiasakan suatu cara kerja di lingkungan masing-masing. Dengan adanya suatu keyakinan dan komitmen kuat merefleksikan nilai-nilai tertentu, misalnya membiasakan kerja berkualitas, sesuai standar, atau sesuai ekpektasi pelanggan (organisasi), efektif atau produktif dan efisien.

Dalam lembaga pendidikan, guru adalah penentu kualitas pendidikan di mana mereka terlibat secara langsung dalam proses pembelajaran di sekolah. Untuk itu guru dituntut untuk 
memberikan kinerja yang professional sesuai dengan tuntutan perkembangan jaman. Salah satu tuntutan terhadap guru adalah harus selalu berupaya untuk mengembangkan diri. Mengingat pentingnya tenaga pendidik dalam menciptakan peserta didik yang berkualiatas, maka kepala madrasah sebagai pengambil keputusan harus memiliki strategi yang tepat dalam menciptakan kehamonisan tenaga pendidik dalam melakukan pekerjaannya sehingga kinerjanya maksimal. Strategi ini hanya dimiliki oleh kepala madrasah yang benar-benar menjalankan tugas pokok fungsinya dengan baik. Kepala madrasah tersebut berusaha untuk mengubah kesadaran guru, membangkitkan semangat dan mengilhami para guru untuk mengeluarkan usaha yang maksimal dalam mencapai tujuan organisasi, tanpa merasa ditekan atau tertekan.

Guru merupakan faktor utama dalam proses pendidikan, oleh karenanya peranan guru dalam sebuah proses pendidikan sangat sentral. Guru yang profesional dengan kinerja maksimal, totalitas dedikasi, dan loyalitas pengabdian dapat dijadikan sebagai tumpuan untuk mengubah kualitas pendidikan menjadi lebih sesuai dengan amanat undang-undang dan tuntutan masyarakat. Guru harus terus berfikir dan membuat secara seksama dalam meningkatakan semangat belajar bagi siswanya dan memperbaiki kualitas mengajarnya. Kehadiran guru dalam proses belajar mengajar belum dapat digantikan sepenuhnya oleh perangkat teknologi. Guru harus selalu meningkatkan dan mengembangkan kemampuannya sehingga keprofesionalan mengajar akan tampak dalam proses belajar mengajar.

Wirawan (2009: 5) mengartikan kinerja sebagai keluaran yang dihasilkan oleh fungsi-fungsi atau indikator-indikator suatu pekerjaan atau suatu profesi dalam waktu tertentu. Kinerja merupakan gambaran mengenai hasil kerja seseorang yang berkaitan dengan tugas yang menjadi tanggung jawabnya. Kinerja guru akan bermakna jika guru selalu menyadari akan kekurangan yang ada pada dirinya. Seorang guru senantiasa dituntut untuk meningkatkan kemampuan atau kompetensi ke arah yang lebih baik, sehingga kinerja yang dihasilkan akan terus meningkat dari waktu ke waktu. Kesadaran ini merupakan bagian dari proses untuk terus belajar mengembangkan dan meningkatkan professionalitas dalam pekerjaannya sebagai tenaga pendidik.

Kenyataan di Kabupaten Demak menunjukkan kondisi yang berbeda, di mana masih banyak tenaga pendidik, dalam hal ini guru Madrasah Tsanawiyah yang belum mampu menunjukkan kinerjanya yang memadai. kinerja guru yang belum memadai ini menjadi salah satu penyebab timbulnya permasalahan pendidikan dan lembaga pendidikan di bawah naungan Kantor Kementerian Agama Demak.

Tujuan utama penelitian ini adalah untuk mengetahui seberapa besar kontribusi peran kepala madrasah dan budaya kerja terhadap kinerja guru madrasah tsanawiyah di kabupaten Demak Jawa Tengah.

\section{METODE PENELITIAN}

Penelitian ini dilakukan pada tahun pelajaran 2017/2018 pada Madrasah Tsanawiyah di Kabupaten Demak Jawa Tengah dengan menggunakan pendekatan kuantitatif. Populasi penelitian adalah guru Madrasah Tsanawiyah Negeri dan Swasta di Kabupaten Demak, sampel sebanyak 135 guru dipilih menggunakan metode kuota purposive random sampling pada madrasah yang terkareditasi minimal B yang tersebar pada 3 (tiga) Kelompok Kerja Madrasah.

Teknik pengumpulan data pada penelitian ini diambil dengan menggunakan angket (kuesioner). Kuesioner merupakan teknik pengumpulan data yang dilakukan dengan cara memberi seperangkat pertanyaan atau pernyataan tertulis kepada responden untuk dijawabnya. (Sugiyono, 2010: 199). Variabel peran kepala madrasah diukur melalui 7 (tujuh) indikator dengan 36 pertanyaan, variabel budaya kerja guru diukur melalui 5 (lima) indikator dengan 22 pertanyaan dan variabel kinerja guru diukur melalui 4 (empat) indikator dengan 20 pertanyaan.

Sugiyono (2010: 178) uji validitas untuk mengetahui kesahihan instrumen bila korelasi tiap faktor tersebut positif dan besarnya $>0,3$ apabila lebih kecil dari 0,3 maka pertanyaan kuesioner yang diajukan tidak valid. Untuk mengetahui apakah kuesioner yang digunakan valid atau tidak, maka $r$ yang diperoleh $\left(r_{\text {hitung }}\right)$ harus dibandingkan dengan $\left(r_{\text {tabel }}\right)$ dengan taraf signifikan 5\% apabila $r_{\text {hitung }}>r_{\text {tabel }}$ maka instrumen dikatakan valid. Uji validitas instrument dilakukan terhadap 30 guru diluar sampel pada beberpa Madrasah. Uji reliabilitas dilakukan terhadap intrumen yang telah dinyatakan valid dengan melihat nilai Cronbach Alpha. Nilai batas yang digunakan untuk tingkat reliabilitas yang dapat diterima adalah diatas 
0,70 . Jika nilainya dibawah 0,70 maka pertanyaan kuesioner yang diajukan tidak reliabel.

Tabel 1 Hasil Uji Reliabilitas Instrumen

\begin{tabular}{|c|c|c|c|}
\hline $\begin{array}{c}\text { Variabel } \\
\text { penelitian }\end{array}$ & $\begin{array}{c}\text { Batas } \\
\text { Ambang }\end{array}$ & $\begin{array}{c}\text { Cronbach's } \\
\text { Alpha }\end{array}$ & Ket \\
\hline $\begin{array}{l}\text { Peran Kepala } \\
\text { Madrsah }\end{array}$ & 0,70 & .966 & eliabel \\
\hline Budaya Kerja & 0,70 & 907 & $\mathrm{Re}$ \\
\hline Kinerja Guru & 0,70 & .873 & Reliabel \\
\hline
\end{tabular}

Analisis data dimulai dengan melakukan uji norrnalitas data setiap variabel, uji linearitas dan selanjutnya dilakukan uji regresi, baik regersi tunggal maupun regresi ganda.

\section{PEMBAHASAN \\ Deskripsi data Penelitian}

Deskripsi data penelitian menggambarkan data yang diperoleh dari penyebaran kuesioner penelitian kepada responden. Data dari sampel sebanyak 135 guru Madrasah Tsanawiyah di Kabupaten Demak Jawa Tengah terhadap 3 (tiga) variabel penelitian yaitu peran kepala madrasah, budaya kerja dan kinerja guru di peroleh hasil sebagaimana tabel di bawah ini;

Tabel 2. Data Hasil Penelitian

\begin{tabular}{lllll}
\hline & Peran kepala Madrasah $\left(\mathrm{X}_{1}\right)$ & Budaya kerja guru $\left(\mathrm{X}_{2}\right)$ & Kinerja guru madrasah $(\mathrm{Y})$ \\
\hline $\mathrm{N}$ & \multicolumn{1}{l}{ Valid } & 135 & 135 & 135 \\
\cline { 2 - 4 } & Missing & 0 & 0 & 0 \\
\hline Mean & 154.2000 & 94.9778 & 87.4593 \\
Variance & 134.728 & 45.067 & 58.832 \\
Minimum & 92.00 & 68.00 & 61.00 \\
Maximum & 180.00 & 108.00 & 99.00 \\
\hline
\end{tabular}

Berdasarkan tabel 2, dapat dijelaskan bahwa variabel peran kepala madrasah diperoleh nilai minimum 92 dan nilai maksimum 180 dengan range score 88 dan nilai mean 154 . Variabel budaya kerja guru diperoleh nilai minimum 68 dan nilai maksimum 108 dengan range score 40 dan mean 94. Variabel kinerja guru diperoleh nilai minimum 61 dan nilai maksimum 99 dengan range score 28 dan nilai mean 87.

Variabel peran kepala madrasah yang diperoleh skor tertinggi 180 dan skor terendah 92 dengan nilai mean 154. Persepsi responden terhadap peran kepala madrasah dikelompokkan menjadi 5 kategori yaitu: sangat baik, baik, cukup baik, kurang baik dan tidak baik. Dengan nilai mean 154 dapat disimpulkan bahwa peran kepala madrasah pada Madrasah Tsanawiyah di Kabupaten Demak dikategorikan baik sebagaimana tabel 3 di bawah ini.

Tabel 3 Persepsi Responden terhadap Peran Kepala Madrasah.

\begin{tabular}{lllc}
\hline Interval & Kriteria & Frekuensi & $(\%)$ \\
\hline $163-180$ & Sangat baik & 28 & $12 \%$ \\
$145-162$ & Baik & 85 & $25 \%$ \\
$127-144$ & Cukup baik & 19 & $35 \%$ \\
$109-126$ & Kurang baik & 2 & $1.5 \%$ \\
$90-108$ & Tidak baik & 1 & $0.7 \%$ \\
\hline Jumlah & & 135 & $100 \%$ \\
\hline
\end{tabular}

Variabel budaya kerja guru yang diukur dengan 5 indikator dan 22 pertanyaan, dari 135 responden diperoleh skor tertinggi 108 dan skor terendah 68 dengan nilai mean 95. Persepsi responden terhadap budaya kerja guru madrasah dikelompokkan menjadi 5 kategori yaitu: sangat baik, baik, cukup baik, kurang baik dan tidak baik. Dengan nilai mean 95 dapat disimpulkan bahwa budaya kerja guru pada Madrasah Tsanawiyah di Kabupaten Demak dikategorikan baik sebagaimana tabel 4 di bawah ini.

Tabel 4 Persepsi Responden terhadap Budaya Kerja

\begin{tabular}{lllc}
\hline Interval & Kriteria & Frekuensi & $(\%)$ \\
\hline $101-108$ & Sangat baik & 28 & $12 \%$ \\
$93-100$ & Baik & 62 & $25 \%$ \\
$85-92$ & Cukup baik & 37 & $35 \%$ \\
$77-84$ & Kurang baik & 6 & $18 \%$ \\
$68-76$ & Tidak baik & 2 & $10 \%$ \\
\hline Jumlah & & 135 & $100 \%$ \\
\hline \multicolumn{2}{c}{ Variabel kinerja guru madrasah yang }
\end{tabular}
diukur dengan 4 indikator dan 20 pertanyaan, dari 135 responden diperoleh skor tertinggi 99 dan skor terendah 61 dengan nilai mean 87. Persepsi responden terhadap kinerja guru madrasah tsanawiyah dikelompokkan menjadi 5 kategori 
yaitu: sangat baik, baik, cukup baik, kurang baik, dan tidak baik. Dengan nilai mean 87 dapat disimpulkan bahwa kinerja guru Madrasah Tsanawiyah di Kabupaten Demak dikategorikan baik sebagaimana tabel 5 di bawah ini.

Tabel 5 Persepsi Responden terhadap Kinerja Guru

\begin{tabular}{lllc}
\hline Interval & Kriteria & Frekuensi & $(\%)$ \\
\hline $94-101$ & Sangat baik & 39 & $12 \%$ \\
$86-93$ & Baik & 46 & $25 \%$ \\
$78-85$ & Cukup baik & 20 & $35 \%$ \\
$70-77$ & Kurang baik & 12 & $18 \%$ \\
$61-69$ & Tidak baik & 3 & $10 \%$ \\
\hline Jumlah & & 135 & $100 \%$ \\
\hline
\end{tabular}

\section{Hasil Uji Dimensi Variabel Penelitian}

Pengujian terhadap dimensi-dimensi pada variabelpenelitian dimaksudkanuntukmnengetahui dimensi/ indikator variabel yang dipersepsikan oleh responden paling baik dan paling jelek/buruk. Hasil uji faktor juga dimaksudkan untuk menyususn prioritas langkah-langkah perbaikan yang seharusnya dilakukan oleh pemangku kepentingan pada Madrasah Tsanawiyah tersebut.

Tabel 12 Hasil Uji Indikator Peran Kepala Madrasah

\begin{tabular}{lll}
\hline Dimensi Variabel & Initial & Extraction \\
\hline X1.1 (Educator) & 1.000 & .578 \\
X1.2 (Manager) & 1.000 & .347 \\
X1.3 (Adminstrator) & 1.000 & .686 \\
X1.4 (Supervisor) & 1.000 & .541 \\
X1.5 (Leader) & 1.000 & .627 \\
X1.6 (Inovator) & 1.000 & .339 \\
X1.7 (Motivator) & 1.000 & .522 \\
\hline
\end{tabular}

Extraction Method: Principal Component

Analysis.

Berdasarkan tabel 12 di atas dapat di jelaskan bahwa indikator inovator dan manajer pada peran kepala madrasah di Madrasah Tsanawiyah Kabupaten Demak dipersepsikan oleh responden kategori rendah dengan nilai 0.339 dan 0,347 dibandingkan dengan lima indikator lainnya. Indikator administrator dipersepsikan paling baik dengan nilai 0,686 , selanjutnya indikator leader dengan nilai 0,627 , educator dengan nilai 0,578 , indikator supervisor dengan nilai 0,541 dan motivator dengan nilai 0,522 .

Kepala Madrasah dalam peran, tugas dan posisinya yang sangat strategis, dituntut memiliki kreativitas, yakni kemampuan untuk mentransformasikan ide dan keinginan-keinginan besar menjadi kenyataan. Keadaan tersebut sangat sulit dicapai apabila seorang kepala madrasah kurang daya innovator dan lemah dalam mamanage dumberdaya madrasah (sebagaimana tabel 12). Untuk menjadi kreatif, seorang kepala madrasah harus memiliki imajinasi, harus memiliki kekuatan ide melahirkan sesuatu yang belum ada sebelumnya. Pelaksanaan inovasi yang dilakukan kepala madrasah di Kabupaten Demak terbukti belum maksimal, misalnya inovasi dalam kurikulum maupun pembelajaran yang terjadi masih terlihat monoton dan rendahnya kualitas madrasah. Beberapa penyebab yang dapat di jadikan asumsi rendahnya inovasi kepala madrasah antara lain:

1. Sekolah atau guru tidak dilibatkan dalam proses perencanaan, penciptaan dan bahkan pelaksanaan inovasi tersebut, sehingga ide baru atau inovasi tersebut dianggap oleh guru bukan miliknya, dan merupakan kepunyaan orang lain yang tidak perlu dilaksanakan, karena tidak sesuai dengan keinginan atau kondisi madrasah mereka.

2. Inovasi yang dibuat oleh kepala madrasah belum sepenuhnya melihat kebutuhan dan kondisi yang dialami oleh guru dan siswa.

Tabel 13 Hasil Uji Indikator Budaya Kerja Guru

\begin{tabular}{lll}
\hline Dimensi Variabel & Initial & Extraction \\
\hline X2.1 (Integritas) & 1.000 & .447 \\
X2.2 (Profesionalisme) & 1.000 & .416 \\
X2.3 (Inovasi) & 1.000 & .367 \\
X2.4 (Tanggung jawab) & 1.000 & .574 \\
X2.5 (Keteladanan) & 1.000 & .623 \\
\hline
\end{tabular}

Extraction Method: Principal Component Analysis.

Berdasarkan tabel 13, di atas dapat di jelaskan bawa indikator inovatif pada budaya kerja guru pada Madrasah Tsanawiyah di Kabupaten Demak dipersepsikan oleh responden paling jelek dengan nilai 0.367 dan budaya profesional guru urutan kedua terendah dibandingkan dengan tiga indikator lainnya. Indikator keteladanan pada budaya kerja guru dipersepsikan paling baik dengan skor 0,623, selanjutnya urutan kedua indikator tanggungjwab dengan nilai 0,574 indikator integritas dengan nilai 0,447 .

Keberhasilan madrasah dalam mengembangkan daya inovasi guru tergantung pada kreativitas individu dan kelompoknya. Artinya, membentuk budaya inovatif berarti aktif 
mendorong seluruh guru untuk berinovasi, bahwa inovasi anggota organisasi merupakan sarana untuk mendorong keberhasilan madrasah. inovasi individual merupakan seperangkat perilaku, dimana serangkaian perilaku tersebut dimulai dari kejelian seseorang mendeteksi kesenjangan dalam pekerjaannya kemudian mencari peluang untuk memperbaikinya.

Kenyataan yang terjadi pada guru madrasah tsanawiyah di Kabupaten Demak inovasi guru masih rendah sebagaimana tabel 13 diatas. Indikasi dari rendahnya inovasi guru dalam budaya kerja antara lain (a) merasa cepat puas dengan hasil yang dicapai madrasah (b) bersikap apatis dalam merespons kebutuhan siswa dan pimpinan (c) rencana pembelajaran dan metode yang tidak berkembang (d) bersikap menolak terhadap ideide pengembangan. Dengan demikian, maka dalam pembaharuan madrasah, keterlibatan guru mulai dari perencanaan inovasi pembelajaran sampai dengan pelaksanaan dan evaluasinya memainkan peran yang sangat besar bagi keberhasilan pembelajaran.

Kepala madrasah dalam membangun budaya kerja yang inovatifa tnpa melibatkan para guru, maka sangat mungkin mereka akan menolak inovasi yang diperkenalkan kepada mereka. Hal ini seperti diuraikan sebelumnya, karena mereka menganggap inovasi yang tidak melibatkan mereka adalah bukan miliknya yang harus dilaksanakan, tetapi sebaliknya mereka menganggap akan mengganggu ketenangan dan kelancaran tugas mereka. Oleh karena itu, dalam suatu inovasi kerja, gurulah yang utama dan pertama terlibat karena guru mempunyai peran yang luas sebagai pendidik, sebagai orang tua, sebagai teman, sebagai motivator bagi siswa.

Tabel 14 Hasil Uji Indikator Kinerja Guru

\begin{tabular}{lll}
\hline Dimensi Variabel & Initial & Extraction \\
\hline Y1.1 (Perencanaan & 1.000 & .447 \\
Pengajaran) & & \\
Y1.2 (Pelaksanaan & 1.000 & .758 \\
Pengajaran) & & \\
Y1.3 (Evaluasi Pengajaran) & 1.000 & .546 \\
Y1.4 (Tindak Lanjut & 1.000 & .579
\end{tabular}

Extraction Method: Principal Component Analysis.

Berdasarkan tabel 14 di atas dapat di jelaskan bawa indikator perencanaan pengajaran pada kinerja guru pada Madrasah Tsanawiyah di
Kabupaten Demak dipersepsikan oleh responden paling jelek dengan nilai 0.447 dan evaluasi pengajaran urutan kedua terendah dibandingkan dengan dua indikator lainnya. Indikator pelaksanaan pengajaran dipersepsikan paling baik dengan nilai 0,758 , selanjutnya indikator tindaklanjut evaluasi pembelajaran dengan nilai 0,579 .

Pembelajaran yang baik akan tercapai apabila disertai dengan perencanaan pengajaran sebagai acuan dalam mengajar. Perencanaan pembelajaran mempunyai peranan penting dalam memandu guru melaksanakan tugasnya sebagai pendidik. Dalam konteks pembelajaran, perencanaan dapat diartikan sebagai proses penyusunan materi pelajaran, penggunaaan media pengajaran, penggunakaan pendekatan dan metode pengajaran dan penilaian dalam suatu alokasi waktu yang akan dilaksanakan pada masa tertentu untuk mencapai tujuan yang telah ditentukan. Membuat rencana mengajar merupakan tugas guru, dimana guru harus mampu menilai kebutuhan siswa sebagai subjek belajar, merumuskan tujuan pembelajaran dan memilih metode serta strategi belajar yang tepat untuk mencapai tujuan yang telah ditetapkan. Dampak yang dapat ditimbulkan karena tidak adanya perencanaan pembelajaran adalah ketidakefektifan guru dalam mengajar. Guru mengajar tidak terarah dan cenderung hanya untuk memenuhi kewajiban mengajar saja. Kurangnya persiapan membuat guru mengajar seadanya sehingga tujuan yang akan dicapai pada proses pembelajaran tersebut tidak dapat tercapai dengan maksimal.

\section{Uji Hipotesis \\ Pengaruh Peran Kepala Madrasah Terhadap Kinerja Guru}

Hasil uji regrsi tunggal variabel peran kepala madrasah terhadap kinerja guru sebagaimana tabel 15 , dapat dijelaskan bahwa diperoleh nilai $R$ square sebesar 0,555 artinya bahwa peran kepala madrasah memiliki pengaruh terhadap kinerja guru sebesar $55,5 \%$ dan sisanya 44,5\% kinerja guru dipengaruhi oleh variabel lain diluar peran kepala madrasah.

Tabel 15 Hasil uji regresi $\mathrm{X}_{1}$ ke $\mathrm{Y}$

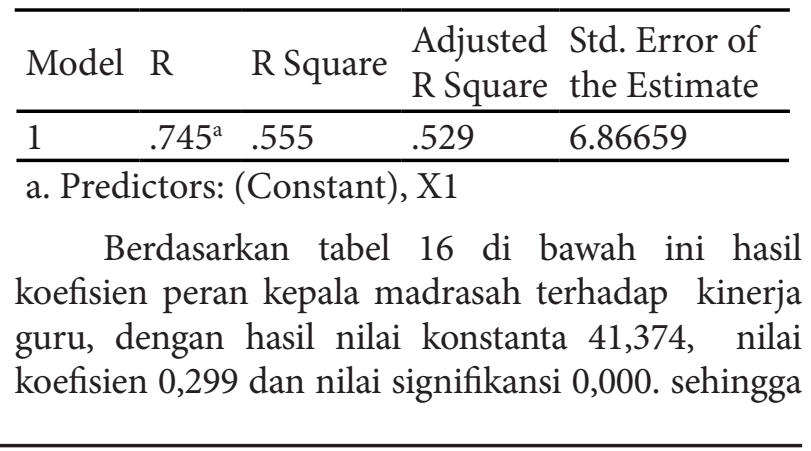


persamaan regresi sebagai berikut: $\hat{\mathrm{Y}}=41,374+$ 0,299 $\mathrm{X}_{1}$. Dapat ditarik kesimpulan bahwa naik turunnya kinerja guru Madrasah Tsanawiyah sangat dipengaruhi oleh peran kepala madrasah. Semakin baik peran kepala madrasah, maka semakin tinggi kinerja guru, demikian pula sebaliknya jika peran kepala madrasah tidak baik, maka kinerja guru akan menurun.

Tabel 16 Koefisien regresi $\mathrm{X}_{1}$ ke $\mathrm{Y}$

\begin{tabular}{lllllll}
\hline \multirow{2}{*}{ Model } & \multicolumn{2}{l}{ Unstandardized Coefficients } & Standardized Coefficients & $\mathrm{t}$ & Sig. \\
\cline { 2 - 5 } & $\mathrm{B}$ & Std. Error & Beta & & \\
\hline 1 & (Constant) & 41.374 & 7.902 & & 5.236 & .000 \\
& $\mathrm{X} 1$ & .299 & .051 & .452 & 5.848 & .000 \\
\hline
\end{tabular}

a. Dependent Variable: $Y$

Peran kepala madrasah sebagai pemimpin suatu lembaga pendidikan merupakan salah satu faktor penting yang sangat mempengaruhi kinerja gurunya. Peran kepala madrasah harus dapat berdampak terhadap semua warga sekolah/ madrasah. Kehadiran pemimpin pada suatu lembaga pendidikan khususnya tidak hanya sebagai simbol saja, tetapi keberadaannya harus memberi dampak posisif bagi perkembangan lembaga pendidikan yang dipimpinnya. Kepala madrasah sebagai pemimpin harus mampu menggerakkan semua sumberdaya yang dimilikinya melalui proses manajemen yang baik, sehingga kinerja sekolah/ madrasah dapat efektif dan efisien. Kepala madrasah idealnya dapat menjadi sumber semangat, inspirasi dan teladan bagi guru-guru dan siswa. Hubungan yang kondisuf dan harmaonis atara pemimpin dan bawahannya akan memberikan dampak positif terhadap moral kerja guru.

Berdasarkan hasil olah data di atas dapat dilihat lebih lanjut tentang pentingnya hubungan peran kepala madrasah terhadap kinerja guru, temuan hasil penelitian di atas mempelihatkan bahwa persepsi guru terhadap peran kepala Madrasah Tsanawiyah di Kabupaten Demak menunjukkan hasil yang menyatakan baik. Korelasi peran kepala sekolah terhadap kinerja guru sebesar 0,745 termasuk dalam kategori kuat sebagaimana. Korelasimya begitu kuat, maka implementasi peran kepala madrasah harus dilaksanakan dengan baik, jika ada perubahan pada peran kepala madrasah akan menunjukkan perubahan pada kinerja guru pada arah yang lebih baik. Sesuai dengan pendapat Suyanto (2013: 39) yang menyatakan peran kepala sekolah akan memberikan pengaruh terhadap apa yang harus dilakukan seorang guru dalam melaksanakan pekerjannya, baik berupa kegiatan, perilaku maupun hasil yang dapat ditunjukkan dalam proses belajar mengajar.
Hasil uji regresi bahwa pengaruh peran kepala madrasah terhadap kinerja guru menunjukkan hasil sebesar 0,555 setara 55,5\%. Hasil ini sangat sesuai dari nilai persepsi guru dan korelasi kedua variabel. Peran kepala madrasah dipersepsikan baik dan korelasi terhadap kinerja guru kuat, pengaruhnya hanya 55,5 \%. Nampak jelas disini bahwa peran kepala madrasah sangat signifikan mempengaruhi kinerja guru. Temuan ini menujukkan bahwa faktor selain peran kepala madrasah yang mempengaruhi kinerja guru masih cuku besar yaitu mencapai $44,5 \%$. Keadaan ini juga memberikan informasi kepada kita bahwa kepala Madrasah Tsanawiyah di Kabupaten Demak secara umum penguruhnya sangat signifikan terhadap kinerja guru.

Hasil penelitian ini jauh jika dibandingkan dengan hasil penelitian sebelumnya yang dilakukan oleh Barinto (2012), hasil penelitian menunjukkan bahwa terdapat hubungan yang signifikan antara peran kepala sekolah dengan kinerja guru sebesar $58,4 \%$.

\section{Pengaruh Budaya Kerja terhadap Kinerja Guru}

Hasil uji regrsi tunggal variabel budaya kerja terhadap kinerja guru sebagaimana tabel 17 , dapat dijelaskan bahwa pengaruh budaya kerja terhadap kinerja guru diperoleh nilai $R$ square sebesar 0,692 artinya bahwa budaya kerja memiliki pengaruh terhadap kinerja guru sebesar 69,2\% dan sisanya $30,8 \%$ kinerja guru dipengaruhi oleh variabel lain diluar budaya kerja

Tabel 17 Hasil uji regresi $\mathrm{X}_{2}$ ke $\mathrm{Y}$

\begin{tabular}{|c|c|c|c|c|}
\hline Model & $\mathrm{R}$ & $\begin{array}{l}\mathrm{R} \\
\text { Square }\end{array}$ & $\begin{array}{l}\text { Adjusted } \\
\text { R Square }\end{array}$ & $\begin{array}{l}\text { Std. Error } \\
\text { of the } \\
\text { Estimate }\end{array}$ \\
\hline 1 & $.832^{\mathrm{a}}$ & .692 & .674 & 5.96861 \\
\hline
\end{tabular}

a. Predictors: (Constant), X2 
Berdasarkan tabel 18 tampak hasil koefisien budaya kerja terhadap kinerja guru, dengan nilai konstanta 38,913 nilai koefisien 0,722 dan nilai signifikansi 0,000 . sehingga persamaan regresinya berikut: $\hat{Y}=38,913+0,722 \mathrm{X}_{2}$. Dapat ditarik kesimpulan bahwa naik turunnya kinerja guru sangat dipengaruhi oleh budaya kerja. Semakin budaya kerja para guru, maka semakin tinggi kinerja guru, demikian pula sebaliknya jika budaya kerja tidak baik, maka kinerja guru akan menurun.

Tabel 18 Koefisien regresi $\mathrm{X}_{2}$ ke $\mathrm{Y}$

\begin{tabular}{lllllll}
\hline \multirow{2}{*}{ Model } & \multicolumn{2}{l}{ Unstandardized Coefficients } & Standardized Coefficients & \multirow{2}{*}{ Sig. } \\
\cline { 3 - 6 } & $\mathrm{B}$ & Std. Error & Beta & & \\
\hline 1 & (Constant) & 38.913 & 7.313 & & 2.586 & .002 \\
& $\mathrm{X} 2$ & .722 & .077 & .632 & 9.397 & .000 \\
\hline
\end{tabular}

a. Dependent Variable: Y

Budaya kerja merupakan salah satu objek dari persepsi, penilaian positif atau negatif terhadap budaya kerja tergantung individu dalam menyeleksi, mengorganisasi, dan menafsirkan informasi yang diterimanya. Budaya kerja merupakan perwujudan dari nilai-nilai yang dimiliki oleh sekelompok manusia atau masyarakat dalam suatu organisasi atau lembaga yang kemudian diolah menjadi nilainilai atau norma serta aturan-aturan baru yang nantinya akan menjadi sikap dan perilaku dalam organisasi yang diharapkan untuk mencapai visi misi dan tujuan.

Budaya kerja guru merupakan seperangkat asumsi yang dibangun dan dianut oleh individu/ organisasi sebagai moral dalam beradaptasi dengan lingkungan eksternal dan proses integrasi internal. Seperangkat asumsi yang dimaksud adalah filosofi, nilai-nilai, norma-norma, keyakinan, ide, mitos, dan karya yang terintegrasi untuk mengarahkan perilaku individual. Seperangkat asumsi tersebut merupakan isi budaya kerja yang berkaitan dengan apa yang dipikirkan, dirasakan dan dilakukan oleh seorang guru. Pelaksanaan budaya kerja tidak dapat dipisahkan dengan peran kepemimpinan dalam suatu organisasi, karena budaya kerja sangat erat kaitannya dengan sikap atau perilaku dan pola pikir guru dalam menciptakan produktivitas kerja yang tinggi. Guru merupakan sebuah elemen terpenting dalam proses pendidikan, oleh karena itu budaya kerja perlu dimiliki dan harus tertanan dalam jiwa guru sebagai pendidik dan pengajar.

Budaya kerja guru pada dasarnya merupakan nilai-nilai yang menjadi kebiasaan seseorang dan menentukan kualitas seseorang dalam bekerja. Budaya kerja guru dapat terlihat dari rasa tanggung jawabnya dalam menjalankan amanah, profesi yang diembannya dan moralitas. Sikap ini akan dibarengi dengan rasa tanggung jawabnya untuk membuat dan mempersiapkan rencana pelaksanaan pembelajaran, pelaksanaan pembelajaran, evalusai, dan analisis serta tindaklanjut pembelajaran. Guru merupakan pendidik profesional dengan tugas utama mendidik, mengajar, membimbing, mengarahkan, melatih, menilai, dan mengevaluasi peserta didik pada setiap jenjang pendidikan. Guru penentu keberhasilan dan kesuksesan anak bangsa, sehingga diperlukan budaya kerja agar kinerjanya optimal. Guno dan Supriyadi $(2003 ; 8)$ budaya kerja merupakan suatu falsafat yang didasari oleh pandangan hidup sebagai nilai-nilai yang menjadi sifat, kebiasaaan dan kekuatan pendorong, membudaya dalam kehidupan suatiu organisasi/ kelompok masyarakat kemudian tercermin dalam dari sikap menjadi perilaku, kepercayaan, cita-cita dan pendapat yang terwujud sebagai kerja atau bekerja.

Dilihat dari hasil olah data tentang budaya kerja, temuan hasil penelitian mempelihatkan bahwa budaya kerja guru Madrasah Tsanawiyah di Kabupaten Demak dipesepsikan responden termasuk kategori baik. Sedangkan korelasi antara variabel budaya kerja terhadap kinerja guru sebesar 0,832 termasuk dalam kategori kuat. Korelasi yang kuat, memberikan informasi bahwa kinerja guru akan sangan dipengaruhi oleh budaya kerja dari guru tersebut, maka implementasi budaya kerja seorang kepala madrasah harus melakukan peran dan fungsinya yang lebih baik agar kinerja gruru menjadi lebih baik.

- Hasil uji regresi tentang pengaruh budaya kerja terhadap kinerja guru menunjukkan hasil sebesar 0,399 setara 39,9 \%. Hasil ini sangat jauh dari nilai persepsi guru dan korelasi kedua variabel. Budaya kerja dipersepsikan baik dan korelasi terhadap kinerja guru kuat, tetapi pengaruhnya hanya $39,9 \%$. Nampak jelas disini bahwa budaya 
kerja masih bersifat formalitas dan rutinitas belum mempunyai hasil signifikasi yang btinggi terhadap kinerja guru. Temuan ini menujukkan bahwa faktor selain diluar budaya kerja yang mempengaruhi kinerja guru mencapai $60,1 \%$. Keadaan ini juga memberikan informasi kepada kita bahwa budaya guru Madrasah Tsanawiyan di Kabupaten Demak secara umum belum baik pengaruhnya terhadap kinerja guru.

Kondisi kinerja guru sangat dipengaruhi bagaimana budaya kerja guru Madrasah Tsanawiyah menajalankan tugas yang dibebankannya serta kesanggupan menjalankan semua peraturan yang berasa dari induk organisasinya. Dari hasil uji indikator di ketahui bahwa indikator inovatif pada budaya kerja guru madrasah pada Madrasah Tsanawiyah di Kabupaten Demak menunjukkan kondisi paling jelek dengan nilai 0.367 dan budaya kerja profesional guru urutan kedua terendah dibandingkan dengan tiga indikator lainnya. Indikator keteladanan pada budaya kerja guru dipersepsikan paling baik dengan skor 0,623, selanjutnya urutan kedua indikator tanggungjwab dengan nilai 0,574 indikator integritas dengan nilai 0,447 .

Temuaninijugasejalandengantemuantentang peran kepala madrasah yang juga menempatkan peran inovator dan manajer pada peran kepala madrasah di MadrasahTsanawiyahKabupaten
Demak termasuk kategori rendah dengan nilai 0.339 dan 0,347 . Pimpinan dan bawahannya memiliki daya inovator yang rendah maka dapat dipastikan akan sangat mempengaruhi kinerja guru, yang pada akhirnya akan bermuara pada kinerja madrasah yang rendah pula.

Dewi (2008: 21-22), menyebutkan faktorfaktor yang mempengaruhi atau sebagai penyebab timbulnya masalah dalam lingkungan kerja, diantaranya adalah: 1) Beban kerja yang berlebihan; 2) Suasana pergaulan yang kurang kondusif; 3) Karakter yang berbeda-beda; 4) Latar kehidupan yang berbeda-beda; 5) Status sosial ekonomi yang berbeda; 6) Kurangnya pembinaan dari manajemen; 7) Kurangnya training kompetensi; 8) Kurang keterbukaan.

\section{Pengaruh Peran Kepala Madrasah dan Budaya Kerja Terhadap Kinerja Guru Madrasah Tsanawiyah di Kabupaten Demak}

Hasil uji regrsi ganda variabel peran kepala madrasah dan budaya kerja secara bersama-sama terhadap kinerja guru sebagaimana tabel 19, dapat dijelaskan bahwa kedua variabel terhadap kinerja guru diperoleh nilai $R$ square sebesar 0,548 artinya bahwa peran kepala madrasah dan budaya kerja secara bersama-sama memiliki pengaruh terhadap kinerja guru sebesar $54,8 \%$ dan sisanya $45,2 \%$ kinerja guru dipengaruhi oleh variabel lain.

Tabel 19 Hasil uji regresi ganda $\mathrm{X}_{1}$ dan $\mathrm{X}_{2}$ ke Y

\begin{tabular}{lllll}
\hline Model & $\mathrm{R}$ & $\mathrm{R}$ Square & Adjusted R Square & Std. Error of the Estimate \\
\hline 1 & $.740^{\mathrm{a}}$ & .548 & .491 & 5.93813 \\
\hline
\end{tabular}

a. Predictors: (Constant), X2, X1

Berdasarkan tabel 20 di bawah ini, terlihat nilai konstanta 14,025 nilai koefisien $\mathrm{X}_{1}$ sebesar 0,584 dan dan nilai koefisien $\mathrm{X}_{2}$ sebesar 0,637 dengan signifikansi 0,000, maka persamaan regresi pengaruh peran kepala madrasah dan budaya kerja terhadap kinerja guru diperoleh $\hat{Y}=14,025+0,584$ $\mathrm{X}_{1}+0,637 \mathrm{X}_{2}$. Persamaan tersebut dapat dijelaskan jika peran kepala madrasah dan budaya kerja guru dianggap konstan maka kinerja guru mempunyai nilai sebesar 14,025 . Nilai koefisien $\mathrm{X}_{1}$ dan $\mathrm{X}_{2}$ yang positif menunjukkan apabila peran kepala dan budaya kerja guru meningkat maka kinerja guru juga meningkat secara signifikan.

Tabel 20 Koefisien regresi ganda $\mathrm{X}_{1}$ dan $\mathrm{X}_{2}$ ke $\mathrm{Y}$

\begin{tabular}{lllllll}
\hline \multirow{2}{*}{ Model } & \multicolumn{2}{l}{ Unstandardized Coefficients } & \multicolumn{2}{l}{ Standardized Coefficients } & & \multirow{2}{*}{ Sig. } \\
\cline { 3 - 5 } & & $\mathrm{B}$ & Std. Error & Beta & & \\
\hline 1 & (Constant) & 14.025 & 7.938 & & 1.767 & .000 \\
& $\mathrm{X} 1$ & .584 & .054 & .527 & 2.539 & .000 \\
& $\mathrm{X} 2$ & .637 & .094 & .558 & 2.771 & .000 \\
\hline
\end{tabular}

a. Dependent Variable: $\mathrm{Y}$ 
Kepemimpinan pendidikan pada lembaga pendidikan Islam, yaitu kepala madrasah, penting sekali bagi peningkatan kualitas pendidikan. Karena lembaga pendidikan yang dikelola oleh pemimpin yang mengerti komitmen serta berwawasan luas, akan berjalan dengan tertib dan dinamis sesuai dengan kemajuan zaman. Selain itu, kepala madrasah hendaknya juga mengerti kedudukan madrasah di masyarakat, mengenal badan-badan dan lembaga-lembaga masyarakat yang menunjang pendidikan, mengenal perubahan sosial, ekonomi, politik masyarakat, mampu membantu guru dalam mengembangkan program pendidikan sesuai dengan perubahan yang terjadi di masyarakat sekaligus membantu pemecahan permasalahan yang dihadapi.

Peningkatan kualitas pendidikan bukanlah suatu hal yang mudah untuk diwujudkan. Karena banyaknya faktor-faktor yang mempengaruhinya yang tanpa ada usaha utnuk meperhatikan dan mencari solusi, maka usaha peningkatan kualitas pendidikan mustahil akan terwujud. Realitanya, banyak lembaga pendidikan yang dapat tumbuh dan berkembang menjadi lebih baik dan ada pula yang mengalami kemandekan dan bahkan tinggal menunggu kehancurannya. Adapun salah satu faktor penyebabnya adalah terletak pada kompetensi dan kepemimpinan kepala madrasah dalam mengelola madrasah.

Apabila seorang kepala madrasah tidak bisa mengatur, mempengaruhi, mengajak anggotanya untuk meraih tujuan pendidikan, gagap memanfaatkan peluang yang ada, dan cenderung menerapkan gaya kepemimpinan yang sekedar melaksanakan tugas rutin, maka jangan diharapkan kualitas pendidikan akan mengalami peningkatan. Sebaliknya, jika seorang kepala madrasah tersebut memiliki potensi yang cukup baik, maka ia akan cenderung untuk terus meningkatkan organisasi pendidikan di lembaga yang dipimpinnya. Sehingga dengan sendirinya kualitas pendidikan ikut meningkat.

Budaya kerja berbeda antara organisasi satu dengan yang lainnya, hal itu dikarenakan landasan dan sikap perilaku yang dicerminkan oleh setiap orang dalam organisasi berbeda. Budaya kerja yang terbentuk secara positif akan bermanfaat karena setiap anggota dalam suatu organisasi membutuhkan sumbang saran, pendapat bahkan kritik yang bersifat membangun dari ruang lingkup pekerjaaannya demi kemajuan di lembaga pendidikan tersebut, namun budaya kerja akan berakibat buruk jika pegawai dalam suatu organisasi mengeluarkan pendapat yang berbeda hal itu dikarenakan adanya perbedaan setiap individu dalam mengeluarkan pendapat, tenaga dan pikirannya, karena setiap individu mempunyai kemampuan dan keahliannya sesuai bidangnya masing-masing.

Berdasarkan uraian deskripsi data di atas, temuan hasil penelitian mempelihatkan bahwa persepsi responden terhadap kinerja guru Madrasah Tsanawiyah di Kabupaten Demak dikategorikan baik. Hasil uji indikator terhadap kinerja guru menunjukkan bahwa indikator perencanaan pengajaran pada kinerja guru madrasah di Kabupaten Demak masuk kategori paling jelek dengan nilai 0.447 dan evaluasi pengajaran urutan kedua terendah dibandingkan dengan dua indikator lainnya. Indikator pelaksanaan pengajaran dipersepsikan paling baik dengan nilai 0,758 , selanjutnya indikator tindaklanjut evaluasi pembelajaran dengan nilai 0,579 . Hasil uji persepsi dan realitas indikatornya menunjukkan bahwa guru mempunyai kelemahan dalam membuat perencanaan pembelajaran. Kelemahan pada aspek perencanaan mempunyai dampak yang serius pada kinerja pembelajaran.

Hasil uji regresi ganda pada variabel peran kepala madrasah dan budaya kerja secara bersamasama terhadap kinerja guru diperoleh nilai $R$ square sebesar 0,410 artinya bahwa peran kepala madrasah dan budaya kerja secara bersama-sama memiliki pengaruh terhadap kinerja guru sebesar $41 \%$ dan sisanya 59\% kinerja guru dipengaruhi oleh variabel lain. Persamaan regresi pengaruh peran kepala madrasah dan budaya kerja terhadap kinerja guru diperoleh koefisien yang positi yaitu $\hat{Y}=14,025$ $+0,584 X_{1}+0,637 X_{2}$. Persamaan tersebut dapat dijelaskan jika peran kepala madrasah dan budaya kerja guru $\left(\mathrm{X}_{1}\right.$ dan $\left.\mathrm{X}_{2}\right)$ positif maka kinerja guru juga meningkat secara signifikan.

Disetiap organisasi posisi dan peran pimpinan selalu sangat sentral. Maju dan mundurnya organisasi sangat tergantung pada sejauh mana pimpinan mampu berimajinasi memajukan organisasinya. Demikian pula dalam konteks madrsah sebagai organisasi, maka posisi kepala madrasah juga sangat sentral dalam memajukan lembaga yang dipimpinnya (Suprayogo, 2004: 211). Oleh karena itu, kepala madrasah harus menghindari terciptanya pola hubungan dengan guru yang hanya mengandalkan kekuasaan saja, akan tetapi perlu mengedepankan kerjasama fungsional. Kepala 
madrasah harus menekankan pada kerjasama kesejawatan, menghindari terciptanya suasana kerja yang serba menakutkan dan membosankan, dan senantiasa mendorong rasa percaya diri para stafnya. Dimana kepemimpinan tersebut senantiasa menekankan pada kerjasama atau pelibatan para guru dan karyawan dalam rangka meningkatkan kinerja organisasi.

Kinerja guru di madrasah mempunyai peran penting dalam pencapaian tujuan sekolah/ madrasah. Masalah kinerja menjadi sorotan berbagai pihak, kinerja lembaga pendidikan madrasah akan dirasakan oleh masyarakat dan kinerja guru akan dirasakan oleh siswa atau orang tua siswa. Kepala madrasah sebagai pimpinan harus mampu memberikan petunjuk dan pengawasan, meningkatkan kemauan tenaga pendidik/gurr, membuka komunikasi dua arah, dan mendelegasikan tugas. Kepala madrasah sebagai leader harus memiliki karakter yang khusus yang mencakup kepribadian, keahlian dasar, pengalaman dan pengetahuan professional, serta pengetahuan administrasi dan pengawasan.

\section{Kinerja Guru, Budaya Kerja dan Peran Kepala Madrasah}

Kinerja guru merupakan tolok ukur profesionalismenya sebagai seorang pendidik. Kinerja guru juga tertuang dalam Undangundang RI Nomor 14 Tahun 2005 tentang Guru dan Dosen pasal 20 (a) yang menyatakan bahwa dalam melaksanakan tugas keprofesionalan, guru berkewajiban: merencanakan pembelajaran, melaksanakan proses pembelajaran yang bermutu, serta menilai dan mengevaluasi hasil pembelajaran. Kinerja guru adalah kemampuan dan keberhasilan guru dalam melaksanakan tugastugas pembelajaran yang yang ditunjukkan oleh:

(a) kemampuan menyusun rencana pembelajaran,

(b) kemampuan melaksanakan pembelajaran,

(c) kemampuan melaksanakan hubungan antar pribadi dengan peserta didik, (d) kemampuan melaksanakan penilaian hasil belajar, (e) kemampuan melaksanakan program pengayaan dan (f) kemampuan melaksanakan program remedial (Supardi, 2014: 25).

Budaya kerja adalah kebiasaan yang dilakukan berulang-ulang oleh pegawai dalam suatu organisasi, pelanggaraan terhadap kebiasaan ini memang tidak ada sangsi tegas, namun dari pelaku organisasi secara moral telah menyepakati bahwa kebiasaan tersebut merupakan kebiasaan yang harus ditaati dalam rangka pelaksanaan pekerjaan untuk mencapai tujuan (Nawawi, 2003: 63). Manfaat yang diperoleh dalam menjalankan budaya kerja antara lain (1) menjamin hasil kerja dengan kualitas yang lebih baik, (2) keterbukaan komunikasi, kebersamaan dan kekeluragaan dalam memperbaiki kesalahan kerja, (3) cepat menyesuaikan diri terhadap perkembangan dari luar, (4) mengurangi dan meminimalisir kesalahan data dan informasi.

Mulyasa (2003: 24) menyatakan bahwa peran kepala sekolah adalah kompetensi yang mengacu pada kemampuan melaksanakan sesuatu yang diperoleh melalui pendidikan, kompetensi merujuk pada performance dan perbuatan yang rasional untuk memenuhi spesifikasi tertentu di dalam pelaksanaan tugas-tugas pendidikan. Mulyasa (2009: 126) peran kepala sekolah adalah segala upaya yang dilakukan kepala sekolah sebagai motor penggerak, penentu arah kebijakan sekolah, yang akan menentukan tujuan-tujuan sekolah dan pendidikan pada umumnya direalisasikan.

Sulisyarini (2006; 133) Kepala sekolah sebagai pemimpin pendidikan dituntut untuk melaksanakan tugas dan tanggung jawabnya yang berkaitan dengan kepemimpinan pendidikan dengan sebaik mungkin, termasuk di dalamnya sebagai pemimpin pengajar. Selanjutnya Priansa (2014: 22) menyatakan bahwa kepala madrasah merupakan salah satu komponen pendidikan yang paling berperan dalam meningkatkan kualitas pendidikan. Untuk itu kepala madrasah harus mengetahui tugas-tugas yang harus dilaksanakan.

\section{PENUTUP}

Mengacu pada deskripsi yang dikemukakan sebelumnya, maka dapat ditarik beberapa kesimpulan, sebagai berikut: 1) Persepsi responden terhadapperankepalamadrasah masukkategoribaik, budaya kerja masuk kategori baik dan kinerja guru masuk katgori baik; 2) Dimensi terkuat dari variabel peran kepala madrasah adalah administrator, yang terlemah aalah inovator. Variabel budaya kerja, keteladanan merupakan dimensi terkuat dan inovasi adalah dimensi terlemah. Variabel kinerja guru dimensi pelaksanaan pengajaran yang terkuat dan yang terlemah adalam perencanaan pengajaran; 3) Peran kepala madrasah berpengaruh signifikan terhadap kinerja guru sebesar 55,5\%. Budaya kerja berpengaruh signifikan terhadap kinerja guru sebesar $69,2 \%$. Peran kepala madrasah dan budaya 
kerja secara bersama-sama berpengaruh signifikan terhadap kinerja guru sebesar $54,8 \%$ dan sisanya $45,2 \%$ kinerja guru dipengaruhi oleh variabel lain, dengan koefisien regresi yang positif yaitu $\hat{Y}=14,025+0,584 X_{1}+0,637 X_{2}$. Dapat dijelaskan semakin baik peran kepala madrasah dan budaya kerja, maka kinerja guru akan meningkat secara signifikan.

\section{UCAPAN TERIMA KASIH}

Penulis mengucapkan terima kasih atas saran dan bimbingannya kepada Universitas PGRI Semarang, Kantor Kementerian Agama dan Kepala MTs di Demak JawaTengah yang turut membantu memberikan data dan informasi, juga kepada Redaktur Jurnal Al-Qalam atas termuatnya tulisan ini, semoga tulisan ini memberikan wawasan dalam pendidikan agama di Indonesia.

\section{DAFTAR PUSTAKA}

, Lampiran Peraturan Menteri Pendayagunaan Aparatur Negara Dan Reformasi Birokrasi Nomor 39 Tahun 2012 Tentang Pedoman Pengembangan Budaya Kerja.

Dewi, Rina Puspita (2008). Modul: Menjaga dan Melindungi Budaya Kerja, Sesuai Standar Isi 2006. Jakarta: Yudhistira.

Hakim, Lukman, S, 2014. Nilai-nilai Budaya Kerja Kementerian Agama. Jakarta: Kementerian Agama RI

Hikmah, Mutiara (2014) peran kepala madrasah dalam mengembangkan Budaya sekolah di mts muhamadiyah $3 \mathrm{Al}$ furqan banjarmasin Jurnal: Ta’lim Mutaallim, Vol. 4, No. 8, ISSN 2088-2977 diunduh pada 21
Desember 2016

Mulyasa, E, 2003; Menjadi Kepala Sekolah Profesional Dalam Konteks Menyukseskan MBS dan KBK, PT Remaja Rosdakarya, Bandung.

Mulyasa, E. 2009. Manajemen Berbasis Sekolah. Bandung : PT Remaja Rosdakarya.

Nawawi,Hadari 2003: Manajemen Sumber Daya Manusia, Cetakan kelima, Gajah Mada University Press, Yogyakarta.

Priansa, Donni J, 2014: Manjemen Supervisi \& Kepemimpinan Kepala Sekolah, Bandung: Alfabeta.

Sulistyorini,2006: Manajemen Pendidikan Islam, Surabaya: Elkaf.

Sugiyono, 2010. Metodologi Penelitian. Bandung: CV. Alfabeta

Supardi. 2014. Kinerja Guru. Jakarta: Rajawali Pers.

Suprayogo,Imam 2004: Pendidikan Berparadigma AlQur'an, Aditya Media Bekerjasama dengan UIN Malang Press, Malang.

Supriyadi, Gering dan Guno Tri; 2003: Budaya Kerja Organisasi Pemerintah. Lembaga Administrasi Jakarta

Taulabi, Iman 2016; Kepemimpinan Kepala Madrasah Dan Budaya Kerja Guru Jurnal Tribakti, ISSN : 1411-9919, E-ISSN 2502-3047 Volume 27 Nomor 2 September 2016 diunduh 12 Januari 2017

Undang-Undang Repuplik Indonesia Nomor 14 Tahun 2005 tentang Guru dan Dosen

Undang-Undang RI No. 20 Tahun 2003, Tentang Sistem Pendidikan Nasional, Bandung, Citra

Wahjosumidjo, 2007. Kepemimpinan Kepala Sekolah Tinjauan Teoretik dan Permasalahannya, Jakarta: Raja Grafindo Persada.

Wirawan. (2009). Evaluasi Kinerja Sumber Daya Manusia; Teori Aplikasi dan Penelitian. Jakarta: Kencana Prenada Media Group 